\title{
Inhibition of cell proliferation and induction of apoptosis by Helicobacter pylori through increased phosphorylated p53, p21 and Bax expression in endothelial cells
}

\author{
AKIHIKO KUROSAWA, HIROTO MIWA, MIYOKO HIROSE, ISAO TSUNE, AKIHITO NAGAHARA and \\ NOBUHIRO SATO
}

Department of Gastroenterology, Juntendo University, School of Medicine, 2-1-1, Hongo, Bunkyo-ku, Tokyo 113-8421, Japan

\begin{abstract}
Microcirculation plays a crucial role in mucosal physiological function as well as repair of gastric mucosal damage. Endothelial cell damage is known to disturb microcirculation and suppress angiogenesis. Therefore, the direct effect of Helicobacter pylori on endothelial cells in vitro was investigated with $H$. pylori water extract. The effect of $H$. pylori water extract on cell proliferation and apoptosis of human umbilical vein endothelial cells (HUVECs) was evaluated. The ratio of BrdU-positive HUVECs in both cagA/vacA-positive and -negative $H$. pylori water extract-treated groups was significantly lower at $24 \mathrm{~h}$ than that in the control group, but Escherichia coli water extract did not affect the proliferation of these endothelial cells. Apoptosis was induced by $\boldsymbol{H}$. pylori water extracts after incubation for $24 \mathrm{~h}$ in a cagA/vacA-independent manner. In the mitochondrial permeability transition assay, tetramethylrhodamine methyl ester was accumulated in mitochondria of HUVECs. Western blot analysis showed no difference in the level of total p53 protein in $\mathrm{H}$. pylori water extract-treated and non-treated cells, but the level of phosphorylated p53 protein was increased in the treated cells at 15 and 60 min after addition of the extract. Reverse transcription (RT)-PCR products for p21 and Bax were elevated in the $H$. pylori water extract-treated cells. p21 levels began to increase 0.5-1 $\mathrm{h}$ after addition of the extract, whereas Bax increased in the period 0.5$2 \mathrm{~h}$. H. pylori induced a disturbance of cell proliferation and apoptosis in the vascular endothelial cells which may contribute to gastric mucosal injury and to delayed healing of gastric lesions.
\end{abstract}

\section{Introduction}

Helicobacter pylori infection delays gastric ulcer healing and the eradication of the infection has been shown to heal gastric ulcers as fast as proton pump inhibitors [1-4]. Generally, healing of gastric ulcers requires both epithelial cell restitution and the proliferation of mesenchymal cells, including vascular endothelial cells. Although many in-vivo and in-vitro experimental studies have explored the mechanisms of pathogenesis of $H$. pylori infection, most have focused on impairment of gastric epithelial cell integrity and function [5-7]. However, gastric mucosal microcircula-

Received 14 June 2001; revised version received 5 Nov. 2001; accepted 15 Nov. 2001.

Corresponding author: Dr N. Sato (e-mail: nsato@med. juntendo.ac.jp). tion is known to regulate proliferation of mesenchymal cells and play an important role in the healing of gastric ulcers or other gastric mucosal injuries [6-9].

Angiogenesis at the base of gastric ulcers has been shown to be inhibited by $H$. pylori infection $[10,11]$, suggesting that $H$. pylori infection has implications not only for the disturbance of gastric epithelial cells, but also for angiogenesis in the gastric mucosa. Endothelial cell damage by $H$. pylori may lead to disturbance of microcirculation and suppression of angiogenesis, thereby contributing to delayed ulcer healing. However, the direct effects of this bacterium on endothelial cells have been poorly characterised.

To investigate whether $H$. pylori directly damages the endothelial cells, its effect on cell proliferation and apoptosis needs to be revealed. Previous reports of the 
effects of $H$. pylori on proliferation and apoptosis of epithelial cells described the cellular mechanisms that are mediated by several gene products including $\mathrm{p} 53$, p21, p27, Bak, Bax or Bcl-2 [12-18]. Of these gene products, $\mathrm{p} 53, \mathrm{p} 21$ and $\mathrm{p} 27$ are involved in cell cycle arrest [12], and Bak, Bax or Bcl-2 are closely related to apoptosis of the cells [13]. Exploration of the expression of these gene products may be useful for confirming the experimental observations and for a better understanding of the cellular mechanisms underlying the effects of $H$. pylori on the endothelial cells. Therefore, the effects of $H$. pylori water extract on proliferation and apoptosis of endothelial cells, and the mechanisms, were investigated.

\section{Materials and methods}

Water extracts of H. pylori and Escherichia coli

Water extracts were prepared from two subtypes of $H$. pylori, strains ATCC43504 (cagA/vacA-positive) (obtained from American Type Culture Collection, Manassas, VA, USA) and C0002 (cagA/vacA-negative) (obtained from Otsuka Assay Laboratory, Tokyo, Japan). Bacteria were inoculated on to Brucella agar and cultured in air with $\mathrm{CO}_{2} 10 \%$ at $37^{\circ} \mathrm{C}$ for $72 \mathrm{~h}$. Colonies were harvested with sterile cotton swabs and suspended in distilled water $\left(10^{9}-10^{10} \mathrm{cfu} / \mathrm{ml}\right)$.

E. coli competent strain DH5 $\alpha$ (Takara, Shiga, Japan) was cultured at $37^{\circ} \mathrm{C}$ for $24 \mathrm{~h}$ in $\mathrm{LB}$ broth (Bacto tryptone $10 \mathrm{~g}$, Bacto yeast extract $5 \mathrm{~g}, \mathrm{NaCl} 10 \mathrm{~g}, 5 \mathrm{~N}$ $\mathrm{NaOH} 200 \mu \mathrm{l}$ and amphotericin B $500 \mu \mathrm{g} / \mathrm{L}$ ) and centrifuged at $3000 \mathrm{rpm}$ for $10 \mathrm{~min}$. The pellet was rinsed with sterile distilled water and resuspended in an appropriate volume of distilled water $\left(10^{8}-10^{9} \mathrm{cfu} /\right.$ $\mathrm{ml})$.

Suspensions were held at room temperature for $20 \mathrm{~min}$ before centrifugation at $12000 \mathrm{rpm}$ for $15 \mathrm{~min}$. The supernates were passed through a $0.2-\mu \mathrm{m}$ syringeadapted filter to remove high mol. wt material, consisting mainly of membrane vesicles and whole flagella. The protein concentration was measured by the Bradford method [19].

\section{Endothelial cells}

Human umbilical vein endothelial cells (HUVECs; ATCC) were seeded on to collagen-coated polyethylene dishes (Sumitomo Bakelite, Tokyo, Japan) and cultured in EBM-2 medium (Bio Whittaker, Walkersville, MD, USA), supplemented with the EGM-2 bullet kit (Bio Whittaker) containing long $\mathrm{R}$ insulin-like growth factor-1, human epidermal growth factor and human fibroblast growth factor-B and vascular endothelial growth factor in humidified air with $\mathrm{CO}_{2} 5 \%$ at $37^{\circ} \mathrm{C}$ for 4 days before experiments. Cultured HUVECs were used for experiments between passage 5 and 8 .

\section{Detection of cell proliferation}

An artificial wound was made on HUVEC complete monolayer cell sheets with a rotating silicon tip resulting in a cell-free round area with a constant size $\left(2 \mathrm{~mm}^{2}\right)$ [20]. H. pylori water extract $(0,50,100$, $200 \mu \mathrm{g} / \mathrm{ml})$ or $E$. coli water extract $(200 \mu \mathrm{g} / \mathrm{ml})$ was added to the cell sheets and cultured for $24 \mathrm{~h}$. 5Bromodeoxyuridine (BrdU) was added $22 \mathrm{~h}$ after wounding and incubation continued for a further $2 \mathrm{~h}$. Proliferating cells were detected by indirect immunohistochemical methods with anti-BrdU monoclonal antibody (MAb). The BrdU labelling index - number of BrdU positive cells/total number of cells per unit area $\left(0.02 \mathrm{~mm}^{2}\right)$ - was calculated in control, H. pylori water extract- and $E$. coli water extract-treated groups $(\mathrm{n}=3)$.

\section{Detection of apoptosis}

HUVECs were cultured for $24 \mathrm{~h}$ in the presence of $H$. pylori water extract $(0,50,100,200 \mu \mathrm{g} / \mathrm{ml})$ or $E$. coli water extract $(200 \mu \mathrm{g} / \mathrm{ml})$. Apoptotic cells were detected by a terminal deoxynucleotidyl transferase (TdT)-mediated deoxyuridine triphosphate (dUTP)biotin nick end labelling (TUNEL) method with a fluorescent apoptosis detection system kit (Promega, Madison, WI, USA). The stained cells were recorded on a fluorescence microscope (Axiophot ZVS 3C75DE; Carl Zeiss, Goleta, CA, USA) and Ektachrome Dyna 400 films (Eastman Kodak, Rochester, NY, USA). To calculate the percentage of apoptotic cells, four random fields $\left(0.2 \mathrm{~mm}^{2}\right)$ were examined in a blind manner in each preparation $(\mathrm{n}=3)$.

\section{Mitochondrial permeability transition assay}

To monitor the changes in mitochondrial permeability from the mitochondrial permeability transition (MPT) changes, HUVECs were cultured with $H$. pylori water extract $(0,200 \mu \mathrm{g} / \mathrm{ml})$ for $24 \mathrm{~h}$ then loaded with tetramethylrhodamine methyl ester (TMRM) $0.5 \mu \mathrm{mol}$ $/ \mathrm{L}$ for $10 \mathrm{~min}$ at $37^{\circ} \mathrm{C}$. Nuclear condensation was evaluated by staining with Bisbenzimide H 33342 Fluorochrome (Calbiochem-Novabiochem, La Jolla, CA, USA). Stained cells were observed with an Axiophot fluorescence microscope (Carl Zeiss).

\section{Western blotting for total $p 53$ and phosphorylated p53}

HUVECs were cultured with $H$. pylori water extract $(200 \mu \mathrm{g} / \mathrm{ml})$ for $15 \mathrm{~min}$ and $1 \mathrm{~h}$ and scraped into a lysis buffer - $150 \mathrm{mM} \mathrm{NaCl}, \mathrm{NP} 401.0 \%$, deoxycholate (sodium salt) $0.5 \%$, SDS $0.1 \%, 50 \mathrm{~mm}$ Tris- $\mathrm{HCl}(\mathrm{pH}$ 8.0). Cell lysates were sonicated for $2 \mathrm{~s}$ to reduce sample viscosity. After removing unbroken cells by centrifugation at $10000 \mathrm{rpm}$ for $5 \mathrm{~min}$, the supernate was boiled in Laemmli loading buffer [21] and separated by SDS-PAGE on an acrylamide $10 \%$ gel 
(BioRad Laboratories, Tokyo Japan). Proteins were electroblotted on to polyvinylidene difluoride membranes, which were then blocked in skimmed milk $2 \%$. Membranes were then incubated overnight at $4^{\circ} \mathrm{C}$ with mouse polyclonal antibody to whole p53 (ImmunoBiological Laboratories, Gunma, Japan) or rabbit polyclonal antibody to phosphorylated p53 (Serin 15) (Cell Signaling Technology, Beverly, MA, USA) and specifically bound primary antibody was detected with a horseradish peroxidase-labelled anti-rabbit secondary antibody (Santa Cruz Biotechnology, Santa Cruz, CA, USA) followed by enhanced chemiluminescence. The membrane was drained of excess developing solution, wrapped in Saran Wrap and exposed to X-ray film.

\section{$R N A$ extraction, reverse transcription (RT)-PCR}

Expression of p21 and Bax mRNA was determined by reverse transcription of total RNA followed by PCR analysis (RT-PCR). Total RNA from HUVEC was isolated by TRIzol Reagent (Life Technologies, Frederic, MD, USA) and reverse transcribed with Moloney murine leukaemia virus (M-MLV) reverse transcriptase (Gibco-BRL). The specific primer set used for human p21 was 5'-GCCGAAGTCAGTTCCTT-3' (forward) and $5^{\prime}$-TCATGCTGGTCTGCCGC-3' (reverse), and for human Bax was 5'-TGGCAGCTGACATGTTTT CTGAC-3' (forward) and 5'-TCACCCAACCACCC TGGTCTT-3' (reverse). p21 was amplified in 36 cycles of $30 \mathrm{~s}$ at $95^{\circ} \mathrm{C}$ for denaturing, $1 \mathrm{~min}$ at $52^{\circ} \mathrm{C}$ for annealing and $1 \mathrm{~min}$ at $72^{\circ} \mathrm{C}$ for extension. PCR for Bax was performed for 28 cycles of $30 \mathrm{~s}$ at $94^{\circ} \mathrm{C}, 30 \mathrm{~s}$ at $58^{\circ} \mathrm{C}$ and $30 \mathrm{~s}$ at $72^{\circ} \mathrm{C}$. Human $\beta$-actin served as a positive control. Primers used in this amplification were human $\beta$-actin sense primer (5'-AACACCCCAGC CATGTACGTAG-3') and antisense primer (5'-GTGT TGGCATAGAGGTCTTTACGG-3'). PCR products were separated by electrophoresis in an agarose $2 \%$ gel and visualised by ethidium bromide staining. Product size (bp) was determined with DNA MW Marker 5 (Nippon Gene, Tokyo, Japan) as a standard size marker.

\section{Results}

Inhibition of endothelial cell proliferation by $H$. pylori water extract

The ratio of BrdU-positive HUVECs in both cagA/ vacA-positive and -negative $H$. pylori water extracttreated groups was significantly lower $(\mathrm{p}<0.05)$ than in the control group (Figs. 1 and 2). This reduction occurred in a dose-dependent manner, and there were no different results with either type of water extract (cagA/vacA-positive or -negative). On the contrary, as shown in Fig. 2, addition of E. coli water extract provided a labelling index similar to the control, suggesting that it did not affect proliferation of these endothelial cells.
Induction of apoptosis in endothelial cells by $H$. pylori water extract

Nuclear condensation was observed in the $H$. pylori water extract-treated HUVECs after incubation for $24 \mathrm{~h}$. Furthermore, the ratio of TUNEL-positive to TUNEL-negative cells was greater in the $H$. pylori water extract-treated cells than in untreated cells (Fig. $3)$. As with inhibition of cell proliferation, these effects were observed in a dose-dependent manner $(\mathrm{p}<0.05)$ and were independent of $\operatorname{cag} A$ or $\operatorname{vacA}$ (Fig. 4).

In the MPT assay, TMRM accumulated in mitochondria of HUVECs as shown in Fig. 5. In most of the apoptotic cells with concentrated nucleus in the $H$. pylori water extract-treated group, TMRM fluorescence was not detected in the cytoplasm, suggesting that the apoptotic induction by $H$. pylori water extract was mediated by a mitochondrial pathway.

\section{Western blot analysis of total p53 and phosphorylated p53}

Western blot analysis showed no difference in the level of total $\mathrm{p} 53$ protein at any point during the experiment. However, the level of phosphorylated p53 protein was clearly increased in the $H$. pylori water extract-treated group at 15 and $60 \mathrm{~min}$ after addition of the extract (Fig. 6).

\section{Expression of mRNA for $p 21$ and Bax in $H$. pylori water extract-treated cells}

RT-PCR products representing p21 and Bax transcripts were clearly elevated in the $H$. pylori water extracttreated cells (Fig. 7). p21 levels began to increase 0.5$1 \mathrm{~h}$ after addition of the extract, whereas Bax increased $0.5-2 \mathrm{~h}$ after addition of the extract.

\section{Discussion}

Several studies have described the effect of $H$. pylori infection on the structure and function of endothelial cells [22-25], most focusing on the activation of leucocytes by the bacteria, resulting in leucocyte migration and attachment to the endothelial cells and subsequent disturbance of microvascular circulation [26-30]. In-vitro studies [31] have shown that $H$. pylori induced the expression of interleukin (IL)-8 in gastric endothelial cells and another study demonstrated the mechanism of $\mathrm{H}$. pylori-induced neutrophildependent vascular protein leakage of the stomach, which is regarded as another indirect effect of $H$. pylori. These observations also addressed the link between $H$. pylori infection and the extra-gastric manifestations of these infections in man [32]. The debate over whether $H$. pylori directly modulates the biological response of endothelial cells raises important questions, because endothelial cells regulate microcir- 

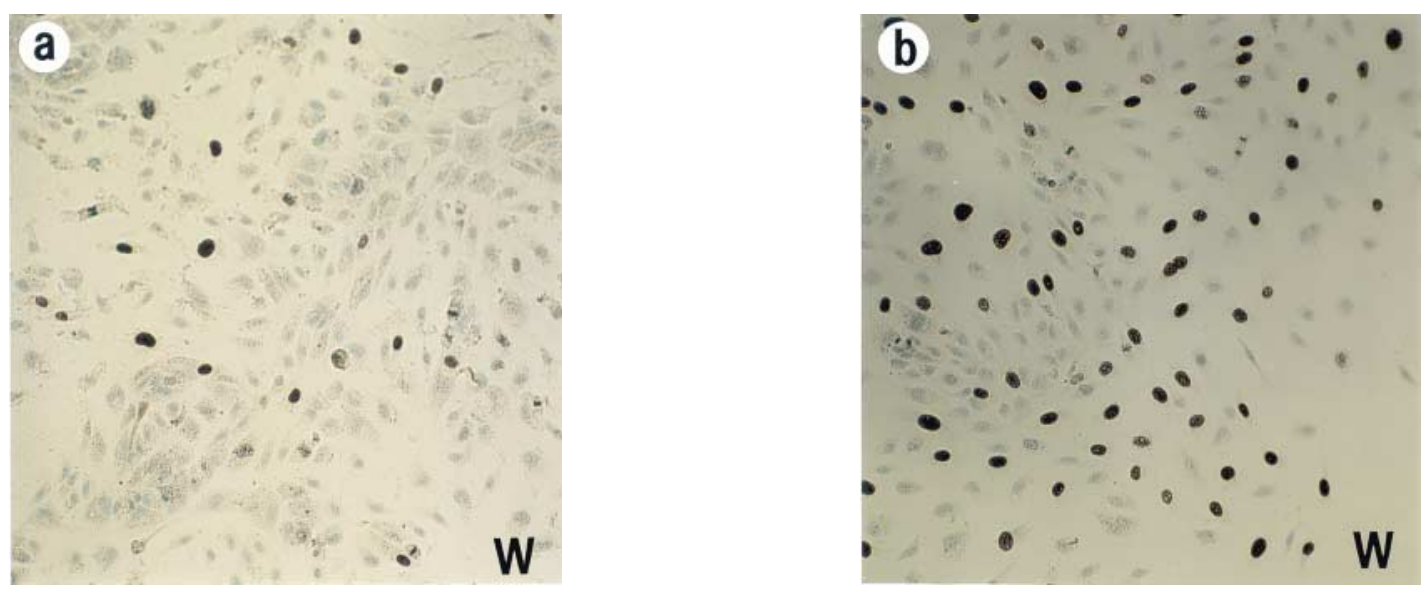

Fig. 1. Inhibition of cell proliferation of HUVECs by H. pylori water extracts. BrdU immunohistochemistry showing the effect of H. pylori water extract from ATCC43504 (cagA/vacA-positive strain, protein concentration $200 \mu \mathrm{g} / \mathrm{ml}$ ) on HUVECs. BrdUpositive cells were lower in the H. pylori water extract-treated group (a) than in non-treated group (b); W, wound.
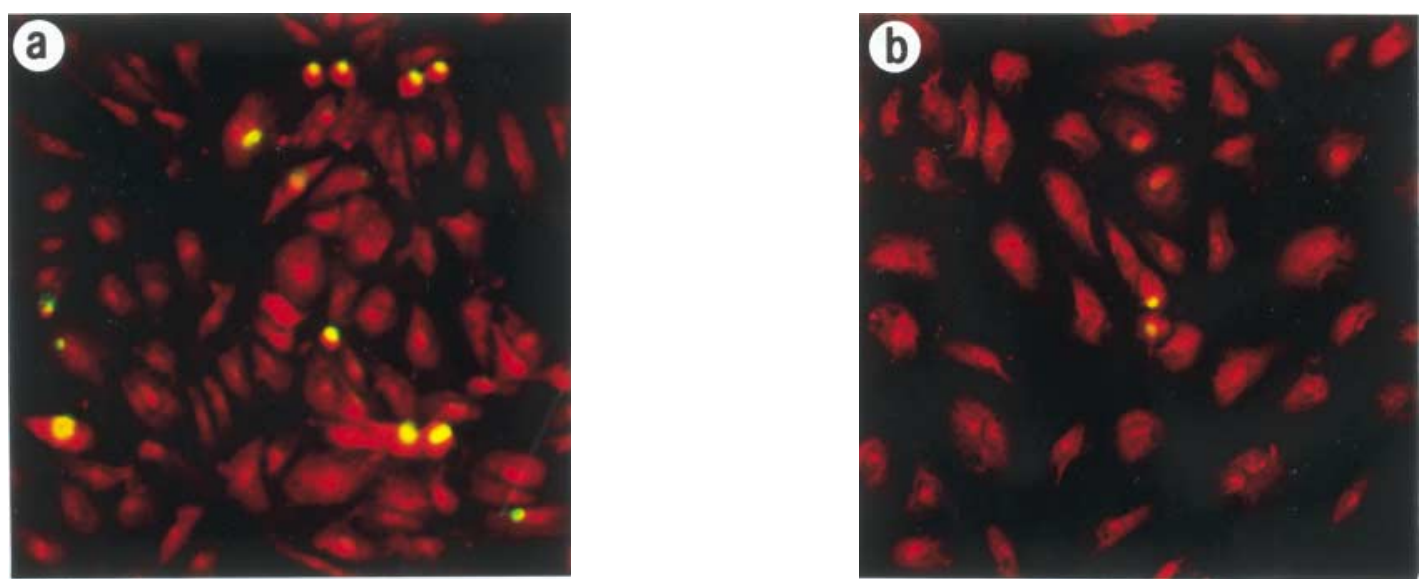

Fig. 3. Apoptosis of HUVECs induced by H. pylori water extracts, TUNEL method staining. Apoptotic cells (yellow fluorescent cells) were increased in the H. pylori water extract (ATCC43504, cagA/vacA-positive strain, protein concentration $200 \mu \mathrm{g} / \mathrm{ml}$ )treated group (a) compared with the non-treated group (b).

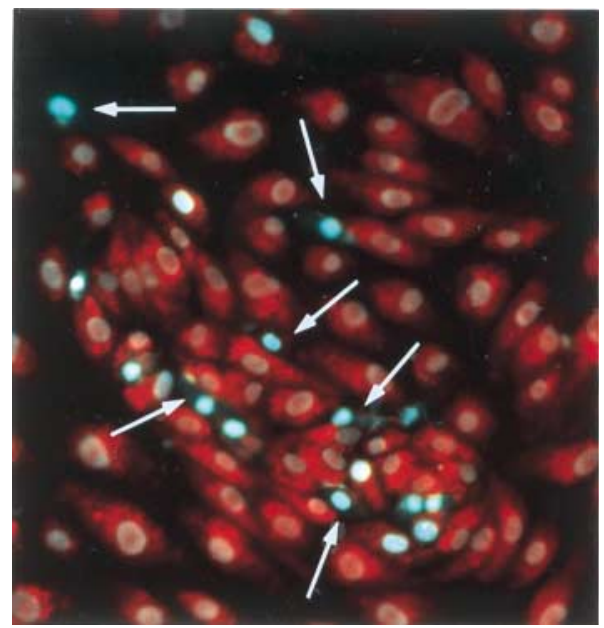

Fig. 5. MPT assay of HUVECs treated with H. pylori water extracts demonstrating mitochondrial injury of HUVECs by addition of $H$. pylori water extract (ATCC43504, cagA/vacApositive strain, protein concentration $200 \mu \mathrm{g} / \mathrm{ml}$ ). MPT were not incorporated in the cytosol of apoptotic cells. The concentrated nucleus in apoptotic cells was tinged by Bisbenzimide $\mathrm{H}$ 33342 Fluorochrome with blue fluorescence (shown by white arrows). MPT-negative apoptotic cells were increased in the $H$. pylori water extract-treated group. culation and disturbance of endothelial cell proliferation impairs angiogenesis during the healing of ulcerative lesions or mucosal damage. Consequently, the present study aimed to clarify whether $H$. pylori itself affects the viability and proliferation of endothelial cells, thereby disturbing the healing process of ulcerative lesions or mucosal damage in the stomach.

The extract prepared from two different strains of $H$. pylori specifically suppressed the proliferation of cultured human endothelial cells, because this phenomenon was caused only by extracts prepared from $H$. pylori but not those prepared from E. coli. The $H$. pylori-specific inhibition of endothelial cell proliferation supports clinical observations of delayed gastric ulcer healing during H. pylori infection. After infection-induced destruction of the gastric surface epithelium, H. pylori might directly affect the endothelial cells. Although $\operatorname{cag} A$ and $v a c A$ have been suggested to be the primary virulence factors for gastric mucosal damage and inducing chemical mediators from gastric cells $[33,34]$, the observation from the present study that $H$. pylori-induced inhibition of the cell prolifera- 


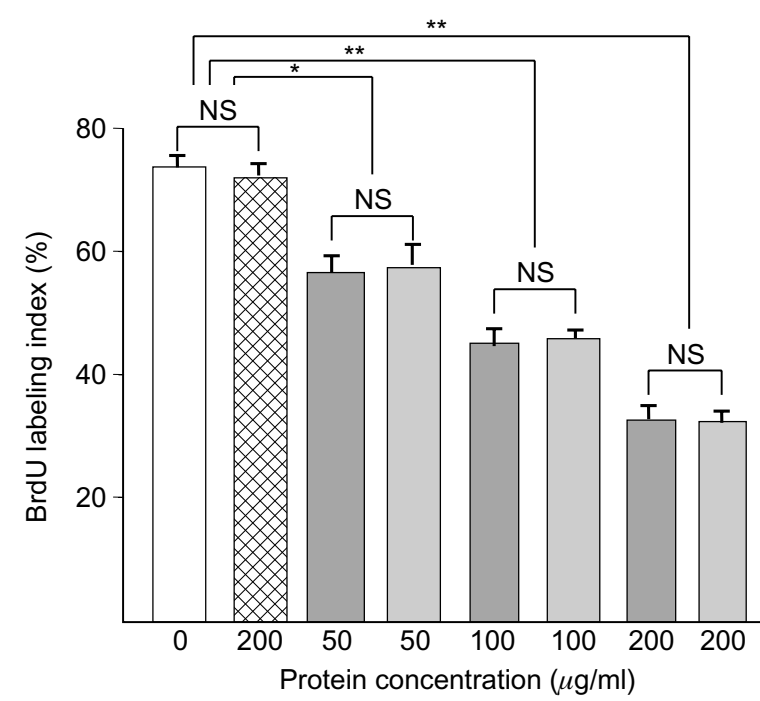

Fig. 2. BrdU labelling index of HUVECs with various concentration of $H$. pylori water extracts. BrdU labelling index decreased in a dose-dependent manner by addition of $H$. pylori water extract, and those of $H$. pylori water extract-treated groups were significantly lower than in the non-treated group. There was no difference between the effects of water extract from cagA/vacA-positive (ATCC43504) ( $\square$ ) and -negative (C0002) ( $\square$ ) strains. (网), E. coli; ( $\square)$, control.

tion was $c a g A / v a c A$-independent supports the idea that other unidentified $H$. pylori water-soluble proteins are critical mediators of its cytotoxic effects. Furthermore, the effects of whole cells of $H$. pylori (ATCC 43504; $\operatorname{cag} A / v a c A$-positive strain) on the cell proliferation were examined in a preliminary way and similar results to those obtained by the water extract were found (data not shown), suggesting that some secreted non $\operatorname{cagA} /$ $v a c A$ proteins may be involved in this cytotoxic effect.

Several other mechanisms by which $H$. pylori might directly suppress the proliferation of vascular endothelial cells were investigated. A previous study by Shirin et al. [14] indicated that $H$. pylori-induced inhibition of

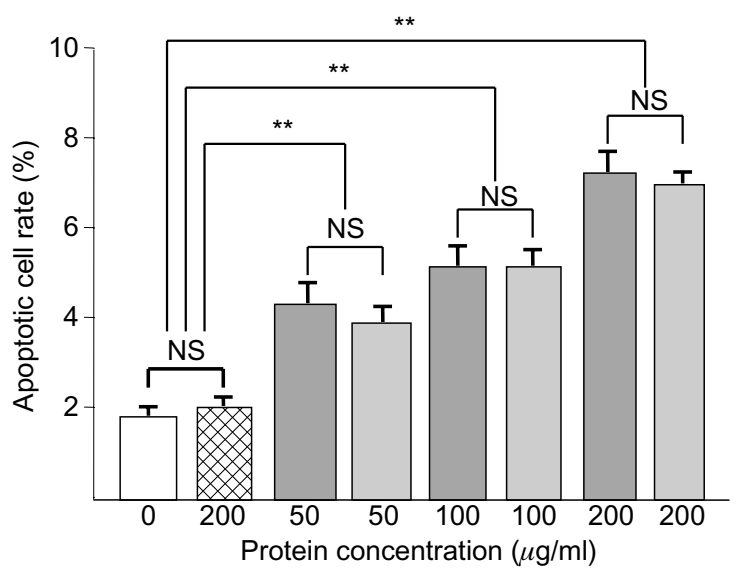

Fig. 4. The ratio of apoptotic HUVECs with various concentrations of $H$. pylori water extracts. The ratio of apoptotic cells increased after addition of $H$. pylori water extract in a dosedependent manner. This effect was independent of $c a g A / v a c A-$ positive (ATCC43504) ( $\square$ ) or -negative (C0002) ( $\square$ ) source of the extract. (国), E. coli; ( $\square)$, control.

the G1-S cell cycle transition in the AGS gastric cancer cell line is associated with reduction of p27 levels but not with reduced $\mathrm{p} 53$ or $\mathrm{p} 21$. Furthermore, H. pylori clinical isolates accelerated the G1 to G2-M transition by a mechanism independent of $\mathrm{p} 53, \mathrm{p} 21$ or $\mathrm{mdm}-2$ gene involvement $[15,16]$. Critically, neither of these studies examined alterations in the level of phosphorylated $\mathrm{p} 53$. The results of the present study indicated that there was no change in the total levels of p53 induced by the $H$. pylori water extract, but instead there was an increase in phosphorylated p53. Several factors may be involved in the difference between the results of the present study and previous studies that gave negative results for the involvement of this tumour suppressor gene. The involvement of p53 phosphorylation in the effect of $H$. pylori water extract on endothelial cells is supported by the accompanying increase in p21 mRNA expression.

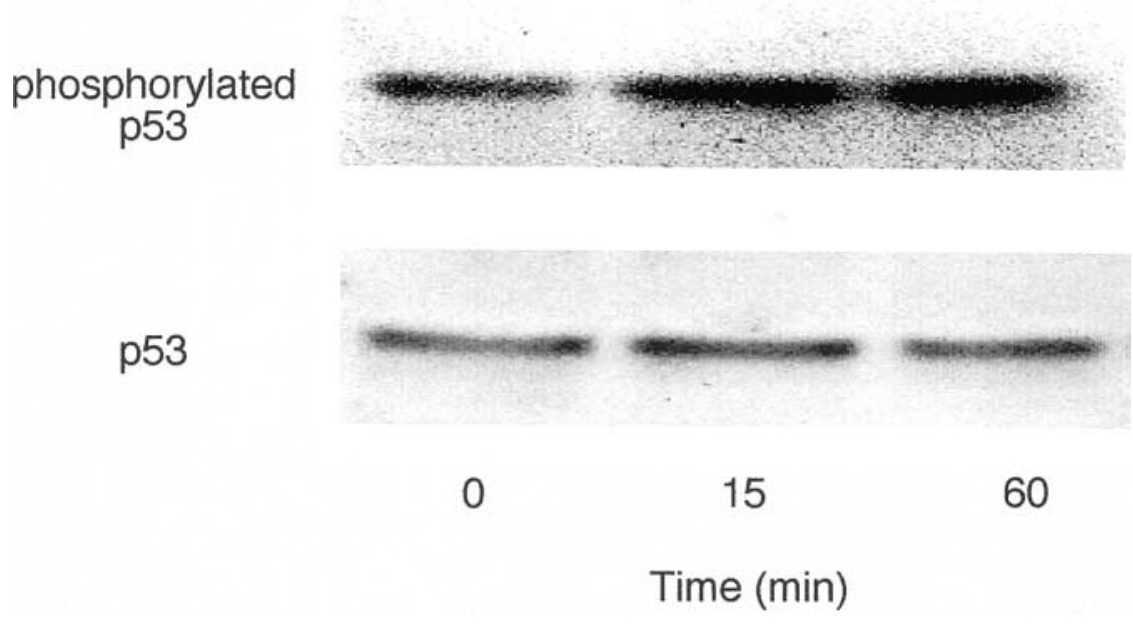

Fig. 6. Western blot analysis of total and phosphorylated p53 levels in the extracted proteins from HUVECs treated with or without H. pylori water extract (ATCC43504, cagA/vacA-positive strain, protein concentration $200 \mu \mathrm{g} / \mathrm{ml}$ ) and anti-p53 and antiphosphorylated p53 antibody. The whole p53 protein was expressed consistently during the time course, the expression of phosphorylated p53 was increased at 15 and 60 min after addition of the water extract (no H. pylori water extract was added at ' 0 min', meaning a basal expression of p53 protein). This result was confirmed by five separate experiments. 

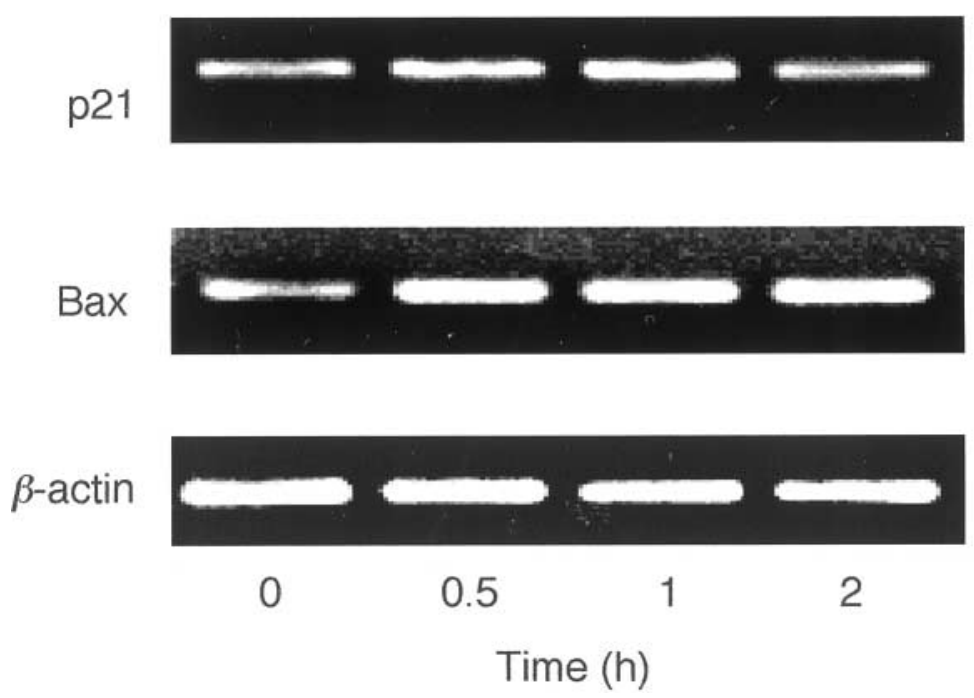

Fig. 7. RT-PCR analysis of p21 and Bax mRNA levels in the HUVECs with or without H. pylori water extract (ATCC43504, cagA/ $v a c A$-positive strain, protein concentration $200 \mu \mathrm{g} / \mathrm{ml}$ ) stimulation. PCR products of $\mathrm{p} 21$ and Bax c-DNA were increased at 0.5 and $1 \mathrm{~h}$, while the intensity of the bands for $\beta$-actin was unchanged, suggesting that $\mathrm{p} 21$ and Bax gene expression were upregulated by the $H$. pylori water extract. This result was confirmed by five separate experiments.

The present study also provided evidence that the $H$. pylori water extract dose-dependently induced apoptosis in HUVECs. The results of the MPT assay suggested that the compromised mitochondrial permeability was associated with this phenomenon. Bax is one of the Bcl-2 family [35] and known to be a key protein relating to apoptosis through mitochondrial injury. Furthermore, as its expression is known to be partially regulated by p53 activity [36], the finding that H. pylori water extract facilitated phosphorylation of p53 protein correlated well with up-regulated Bax expression, i.e., the results demonstrated that the $H$. pylori-induced apoptosis was mediated by the Baxrelated mitochondrial injury. A recent study [17] has described induction of Bax expression and repression of Bcl-2 during mitochondrial-dependent apoptosis, yet only Bak (one of the bcl-2 family) plays a role in apoptosis in the AGS cancer cell line [18]. In addition, Fas-Fas ligand interaction has been implicated in $H$. pylori-induced apoptosis [37]. Establishing the relevance of this pathway, which works through activated monocytes, would require an in-vivo model. The results of the present study raise the possibility that $H$. pyloriinduced endothelial cell apoptosis may not only enhance mucosal injury through extravasation of inflammatory cells, but might also retard mucosal repair through inhibition of angiogenesis. Future invivo studies should clarify the clinical implications of $H$. pylori-induced apoptosis of vascular endothelial cells in gastric mucosal lesions.

\section{References}

1. Sung JJY, Chung SCS, Ling TKW et al. Antibacterial treatment of gastric ulcers associated with Helicobacter pylori. $N$ Engl J Med 1995; 332: 139-142

2. Labenz J, Börsch G. Evidence for the essential role of Helicobacter pylori in gastric ulcer disease. Gut 1994; 35:
$19-22$.

3. Van del Hulst RW, Rauws EA, Köycu B et al. Prevention of ulcer recurrence after eradication of Helicobacter pylori: a prospective long-term follow-up study. Gastroenterology 1997; 113: $1082-1086$.

4. Sakaki N, Momma K, Egawa N, Tu Y, Kato H. Preliminary clinical study on gastric ulcer scars and ulcer relapse after Helicobacter pylori eradication therapy. J Clin Gastroenterol 1997; 25 Suppl 1: S229-S234.

5. Kodama R, Fujioka $T$, Shuto R, Kubota $T$, Nasu $M$. Helicobacter pylori infection delays the healing of acetic acid-induced gastric ulcer in Japanese monkeys. J Gastroenterol Hepatol 1996; 11: 1097-1102.

6. Fujiwara Y, Wyle F, Arakawa $\mathrm{T}$ et al. Helicobacter pylori culture supernatant inhibits binding and proliferative response of human gastric cells to epidermal growth factor: implications for $H$. pylori interference with ulcer healing? Digestion 1997; 58: $299-303$.

7. Li H, Kalies I, Mellgård B, Helander HF. A rat model of chronic Helicobacter pylori infection. Studies of epithelial cell turnover and gastric ulcer healing. Scand J Gastroenterol 1998; 33: $370-378$.

8. Sato N, Kawano S, Kamada T, Takeda M. Hemodynamics of the gastric mucosa and gastric ulceration in rats and in patients with gastric ulcer. Dig Dis Sci 1986; 31: 35S-41S.

9. Sato N, Kawano S, Tsuji S, Kamada T. Microvascular basis of gastric mucosal protection. J Clin Gastroenterol 1988; 10 Suppl 1: S13-S18

10. Tsuji S, Kawano S, Tsujii M et al. [Mucosal microcirculation and angiogenesis in gastrointestinal tract.] Nippon Rinsyo 1998; 56: 2247-2252 (in Japanese).

11. Brzozowski T, Konturek PC, Konturek SJ et al. Water extracts of Helicobacter pylori delay healing of chronic gastric ulcers in rats: role of cytokines and gastrin-somatostatin link. Digestion 1999; 60: 22-33.

12. Pestov DG, Strezoska Z̆, Lau LF. Evidence of p53-dependent cross-talk between ribosome biogenesis and the cell cycle: effects of nucleolar protein Bopl on G (1)/S transition. Mol Cell Biol 2001; 21: 4246-4255.

13. Cheng EH-YA, Wei MC, Weiler S et al. BCL-2, BCL-X (1) sequester bh3 domain-only molecules preventing BAX- and BAK-mediated mitochondrial apoptosis. Mol Cell 2001; 8: 705-711.

14. Shirin H, Sordillo EM, Oh $\mathrm{SH}$ et al. Helicobacter pylori inhibits the G1 to $\mathrm{S}$ transition in AGS gastric epithelial cells. Cancer Res 1999; 59: 2277-2281.

15. Peek RM, Blaser MJ, Mays DJ et al. Helicobacter pylori strain-specific genotypes and modulation of the gastric epithelial cell cycle. Cancer Res 1999; 59: 6124-6131.

16. Donehower LA. Effects of p53 mutation on tumor progression: 
recent insights from mouse tumor models. Biochem Biophys Acta 1996; 124: 171-176

17. Konturek PC, Pierzchalski P, Konturek SJ et al. Helicobacter pylori induces apoptosis in gastric mucosa through an upregulation of bax expression in humans. Scand J Gastroenterol 1999; 34: 375-383.

18. Chen G, Sordillo EM, Ramey WG et al. Apoptosis in gastric epithelial cells is induced by Helicobacter pylori and accompanied by increased expression of BAK. Biochem Biophys Res Commun 1997; 239: 626-632.

19. Zor T, Selinger Z. Linearization of the Bradford protein assay increases its sensitivity: theoretical and experimental studies. Anal Biochem 1996; 236: 302-308

20. Watanabe S, Hirose M, Wang X-E et al. Hepatocyte growth factor accelerates the wound repair of cultured gastric mucosal cells. Biochem Biophys Res Commun 1994; 199: 1453-1460.

21. Castellanos-Serra LR, Fernandez-Patron C, Hardy E, Huerta V. A procedure for protein elution from reverse-stained polyacrylamide gels applicable at the low picomole level: an alternative route to the preparation of low abundance proteins for microanalysis. Electrophoresis 1996; 17: 1564-1572.

22. Shibata J, Goto $\mathrm{H}$, Arisawa $\mathrm{T}$ et al. Regulation of tumor necrosis factor (TNF) induced apoptosis by soluble TNF receptors in Helicobacter pylori infection. Gut 1999; 45: $24-31$.

23. Mine T, Endo C, Kushima R et al. The effect of water extracts of CagA positive or negative Helicobacter pylori on proliferation, apoptosis and connexin formation in acetic acid-induced gastric ulcer of rats. Aliment Pharmacol Ther 2000; 14:

199-204.

24. Slomiany BL, Piotrowski J, Slomiany A. Induction of caspase3 and nitric oxide synthase-2 during gastric mucosal inflammatory reaction to Helicobacter pylori lipopolysaccharide. Biochem Mol Biol Int 1998; 46: 1063-1070.

25. Watanabe S, Takagi A, Koga Y, Kamiya S, Miwa T. Helicobacter pylori induces apoptosis in gastric epithelial cells through inducible nitric oxide. $J$ Gastroenterol Hepatol 2000; 15: $168-174$.

26. Kalia N, Jacob S, Brown NJ, Reed MWR, Morton D, Bardhan KD. Studies on the gastric mucosal microcirculation. 2 . Helicobacter pylori water soluble extracts induces platelet aggregation in the gastric mucosal microcirculation in vivo. Gut 1997; 41: 748-752.

27. Kalia N, Bardhan KD, Reed MWR, Jacob S, Brown NJ Mechanism of Helicobacter pylori-induced rat gastric mucosal microcirculatory disturbances in vivo. Dig Dis Sci 2000; 45: $763-772$.

28. Kalia N, Bardhan KD, Reed MWR, Jacob S, Brown NJ. Effects of chronic administration of Helicobacter pylori extracts on rat gastric mucosal microcirculation in vivo. Dig Dis Sci 2000; 45: 1343-1351.

29. Kurose I, Granger DN, Evans DJ et al. Helicobacter pyloriinduced microvascular protein leakage in rats: role of neutrophils, mast cells, and platelets. Gastroenterology 1994; 107: 70-79.

30. Takemura T, Granger DN, Evans DJ et al. Extract of Helicobacter pylori induces neutrophils to injure endothelial cells and contains antielastase activity. Gastroenterology 1996; 110: $21-29$.

31. Ding S-Z, Cho C-H, Lam S-K. Helicobacter pylori induces interleukin-8 expression in endothelial cells and the signal pathway is protein tyrosine kinase dependent. Biochem Biophys Res Commun 1997; 240: 561-565.

32. Yoshida N, Granger DN, Evans DJ et al. Mechanisms involved in Helicobacter pylori-induced inflammation. Gastroenterology 1993; 105: 1431-1440.

33. Rokkas T, Ladas S, Liatsos $\mathrm{C}$ et al. Relationship of Helicobacter pylori CagA status to gastric cell proliferation and apoptosis. Dig Dis Sci 1999; 44: 487-493.

34. Peek RM, Moss SF, Tham KT et al. Helicobacter pylori cagA strains and dissociation of gastric epithelial cell proliferation from apoptosis. J Natl Cancer Inst 1997; 89: 863-868.

35. Nechushtan A, Smith CL, Lamensdorf I, Yoon S-H, Youle RJ Bax and Bak coalesce into novel mitochondria-associated clusters during apoptosis. J Cell Biol 2001; 153: 1265-1276.

36. Campomenosi P, Monti P, Aprile A et al. p53 mutants can often transactivate promoters containing a p21 but not Bax or PIG3 responsive elements. Oncogene 2001; 20: 3573-3579.

37. Rudi J, Kuck D, Strand S et al. Involvement of the CD95 (APO-1/Fas) receptor and ligand system in Helicobacter pylori-induced gastric epithelial apoptosis. J Clin Invest 1998; 102: 1506-1514. 